\title{
Pesticides in Ground Water - Hot Springs County, Wyoming, 2003-04
}

In 1991, members of local, State, and Federal governments, as well as industry and interest groups, formed the Ground-water and Pesticide Strategy Committee to prepare the State of Wyoming's generic Management Plan for Pesticides in Ground Water. Part of this management plan is to sample and analyze Wyoming's ground water for pesticides. In 1995, the U.S. Geological Survey, in cooperation with the Ground-water and Pesticide Strategy Committee, began statewide implementation of the sampling component of the State of Wyoming's generic Management Plan for Pesticides in Ground Water. During 2003-04, baseline monitoring was conducted in Hot Springs County.

\section{PESTICIDES IN GROUND WATER}

Synthetic organic pesticides are used to control weeds, insects, and other organisms in a wide variety of agricultural and nonagricultural settings. The use of pesticides has helped to make the United States the world's largest producer of food (Barbash and Resek, 1996). Pesticide use, however, has also been accompanied by concerns about potential adverse effects on the environment and human health.
A potential pathway for the transport of pesticides is through hydrologic systems, which supply water for both humans and natural ecosystems. Water is one of the primary ways pesticides are transported from an application area to other locations in the environment (fig. 1) (Barbash and Resek, 1996).

Pesticide contamination of ground water is a national issue because of the widespread use of pesticides, the expense

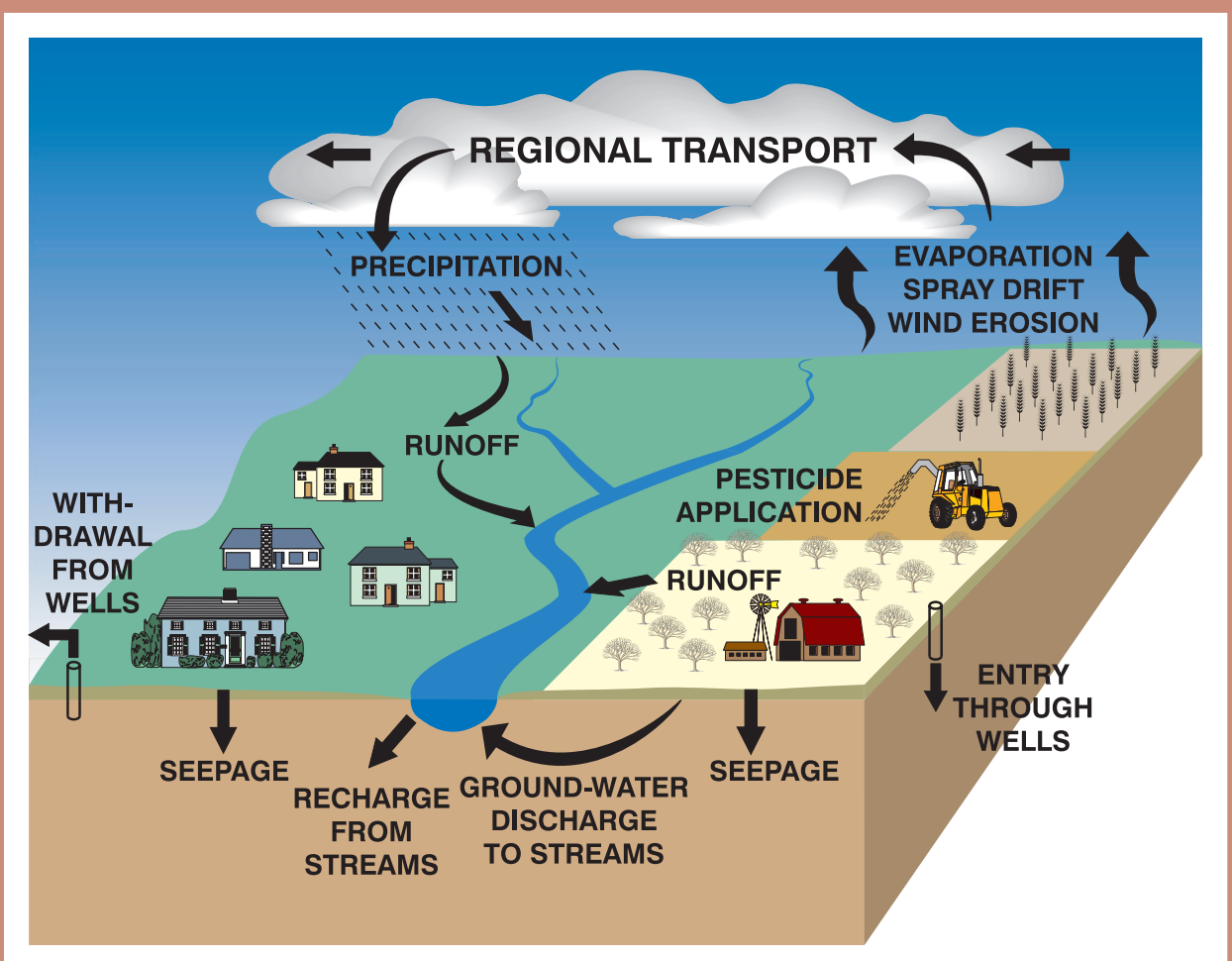

Figure 1. Pathways of pesticide movement in the hydrologic cycle (modified from Barbash and Resek, 1996). and difficulty of remediating ground water, and the fact that ground water is used for drinking water by about half of the Nation's population. Although application rates and the variety of pesticides used may be greater in urban areas, concern over their presence in ground water is especially acute in rural agricultural areas where more than 95 percent of the population rely upon this resource for drinking water (Hutson and others, 2004).

\section{WYOMING'S PESTICIDE MANAGEMENT PLAN}

The Ground-water and Pesticide Strategy Committee (GPSC) has developed the generic State Management Plan for Pesticides in Ground Water for the State of Wyoming (SMP) (Wyoming Groundwater and Pesticides Strategy Committee, 1999). Wyoming was required by the U.S. Environmental Protection Agency to have a SMP in order for individuals and organizations to continue using certain pesticides in the State. The SMP includes information relating to individuals and organizations involved with implementation of the SMP, methods of preventing ground-water contamination, ground-water monitoring, and the responses required if pesticides are detected in ground water.

One critical part of the SMP is groundwater monitoring. This ground-water monitoring program has two phases. The first phase, baseline monitoring, is designed to determine what pesticides, if any, have leached into the county's ground water. 
Table 1. Summary of baseline monitoring for pesticides in Hot Springs County, August 2003 and April 2004.

[ $\mu \mathrm{g} / \mathrm{L}$, micrograms per liter; NA, not applicable; E, estimated concentration; T, trace concentration, value is estimated; C, estimated value used in calculation]

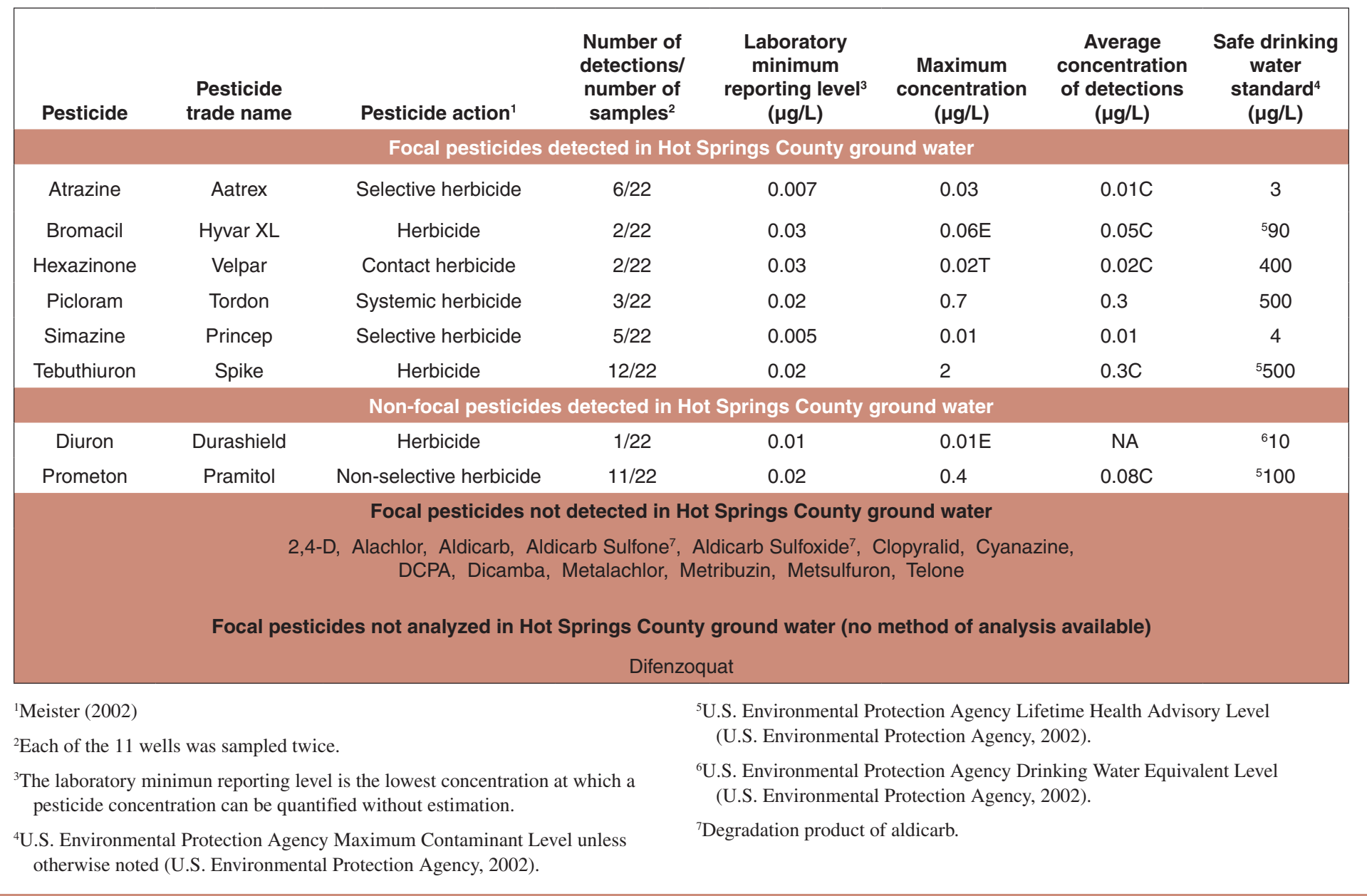

The second phase, problem identification monitoring, is used to gather additional information about the ground water near wells with samples having significant pesticide detections.

Baseline monitoring is prioritized by a county rank and the vulnerability of the county's ground water to pesticides. During the development of the SMP, the GPSC evaluated each county in Wyoming to determine the potential vulnerability of the county's ground water to pesticides. Each county was ranked according to the extent of cropland and urban areas in the county, as well as the amount of pesticides sold within the county in 1991 (Wyoming Ground-water and Pesticides Strategy Committee, 1999).

A ground-water vulnerability map was prepared for the uppermost or shallowest aquifer (Hamerlinck and Arneson, 1998). A Geographic Information System was used to overlay seven layers describing hydrogeology and land use. Ground water is more vulnerable because of either inherent sensitivity of the hydrogeology, or because of the combination of the sensitivity and associated land use. The map was used to assist in the selection of monitoring sites in each county. The monitoring focuses on areas where the ground water is most vulnerable.

The GPSC selected 18 pesticides (focal pesticides) and 2 degradation products to be sampled as part of the SMP (table 1). The analytical method used to detect the focal pesticides can also detect 66 other pesticides and degradation products. Any additional pesticides detected are listed in table 1 as non-focal pesticides. Ground water from all wells in the baseline monitoring program was analyzed for the pesticides listed in table 1, with the exception of difenzoquat, for which analytical methods are not available.

The goal of the ground-water sampling part of the SMP is to collect ground-water samples for pesticide analyses in all 23 Wyoming counties. To date, sampling has been completed in Goshen (1995-96), Park (1997), Washakie (1997-98), Fremont (1998-99), Lincoln (1998-99), Lara- mie (1998-99), Big Horn (1999-2000), Sheridan (1999-2000), Platte (2000-01), Johnson (2000-01), Crook (2000-01), Natrona (2001-02), Sweetwater (2001-02), Teton (2001-02), Uinta (2002-03), Albany (2003-04), Converse (2003-04), and Hot Springs (2003-04) Counties. Sampling began in 2004 in Carbon, Campbell, and Sublette Counties.

\section{GROUND-WATER MONITORING IN HOT SPRINGS COUNTY}

The ground water in Hot Springs County was ranked nineteenth most vulnerable to pesticide contamination in Wyoming (Wyoming Ground-water and Pesticide Strategy Committee, 1999). The vulnerability map created by the Spatial Data and Visualization Center (Hamerlinck and Arneson, 1998), identifies ground water in unconsolidated quaternary deposits in the county (primarily alluvial and terrace deposits) with urban and agricultural land use and the mountainous areas as the most vulnerable to pesticide 


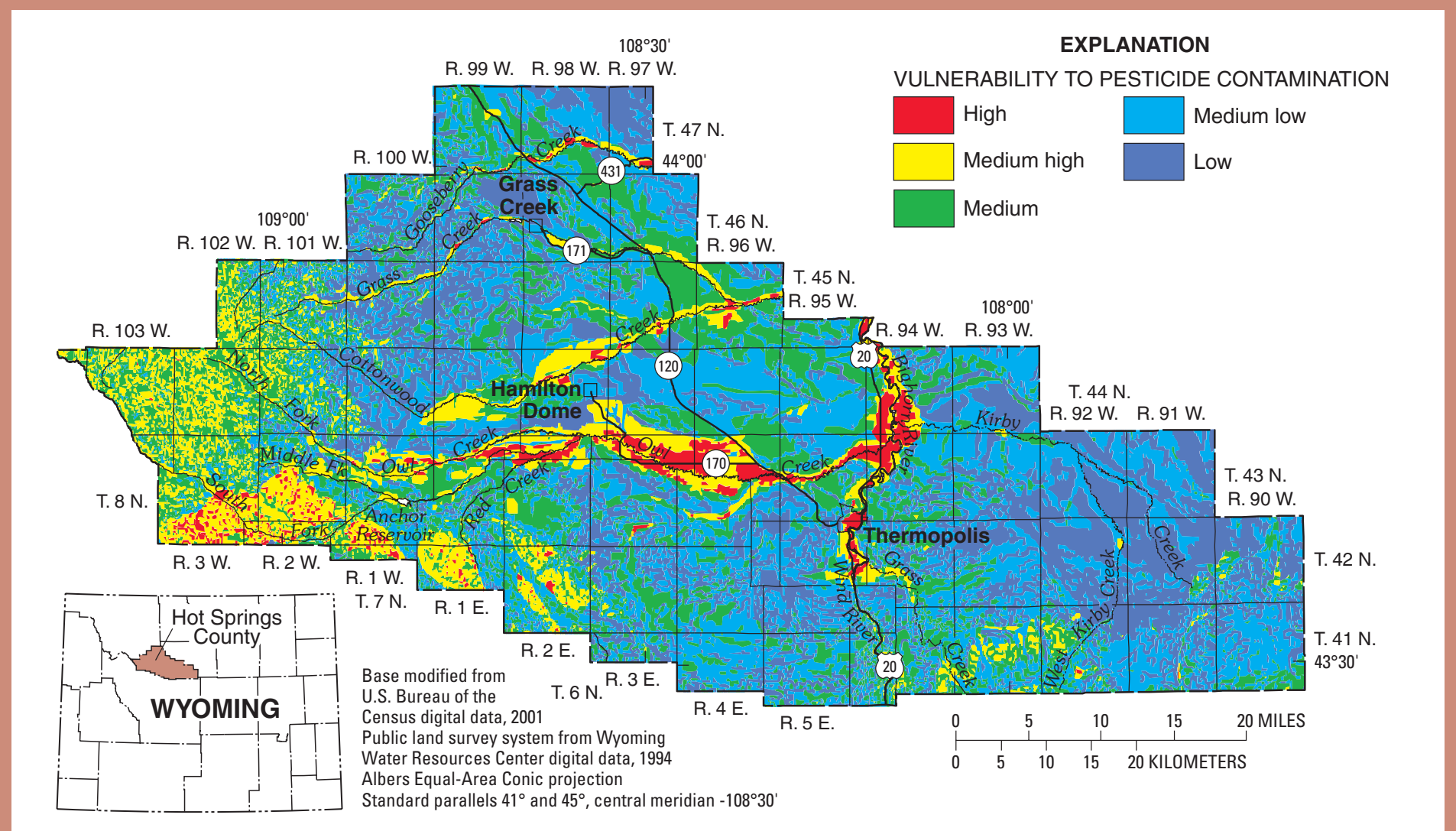

Figure 2. Vulnerability of Hot Springs County, Wyoming ground water to pesticide contamination (from Hamerlinck and Arneson, 1998).

contamination (shown as red on fig. 2). The focus of the sampling was in the alluvial and terrace deposits of the Bighorn River and Owl Creek (fig. 3). The mountainous areas were not sampled because, although the hydrogeology makes the ground water susceptible to contamination, the land use does not create a large potential for contamination.

Eleven wells were selected in Hot Springs County (fig. 3) for baseline monitoring. All wells were located in the Quaternary alluvial or terrace deposits. All wells were sampled in August 2003 and April 2004.

Six of the 19 focal pesticides or degradation products and 2 non-focal pesticides were detected in Hot Springs County (table 1). Pesticides were detected in 7 of the 11 wells sampled in Hot Springs County; concentrations of each pesticide detected were less than $1 / 100$ of the applicable drinking-water standard (U.S. Environmental Protection Agency, 2002) (table 1). About two-fifths of the detections were less than the minimum reporting level, at trace concentrations. A trace concentration (qualified with a " $T$ " in table 1) indicates that the pesticide was detected, but at a concentration too small to quantify without estimation. Estimated concentrations are qualified with an "E" in table 1, if the result was considered an estimate, due to analytical uncertainty.

The most commonly detected pesticide (12 of 22 samples) in Hot Springs County was tebuthiuron. Tebuthiuron is an herbicide used in noncropland areas, rangeland, and right-of-ways (Meister, 2002). Tebuthiuron was also the most commonly detected pesticide in Sweetwater County.

The second most commonly detected pesticide in Hot Springs County was prometon (detected in 11 of 22 samples). Prometon, the active ingredient in the general-use pesticide Pramitol, is typically detected in areas with urban land use (Barbash and others, 1999).

\section{DATA DISTRIBUTION AND AVAILABILITY}

Sampling results have been provided to local groups interested in pesticides in ground water in Hot Springs County. The information can be used by citizens and local governments to help understand current conditions. Analytical results of the Hot Springs County sampling can be found in Swanson and others (2004), and Blajszczak and others (2005), or on the internet at http://waterdata.usgs.gov/wy/ nwis/qwdata. Analytical results and fact sheets for all counties sampled to date are available from the U.S. Geological Survey in Cheyenne either by phone, email, or on the internet at: http://wy.water.usgs. gov/projects/pesticidel.

\section{REFERENCES}

Barbash, J.E., and Resek, E.A., 1996, Pesticides in ground water: Distribution, trends, and governing factors: in Gilliom, R.J., ed., Pesticides in the hydrologic system (v. 2): Lewis Publishers, $590 \mathrm{p}$.

Barbash, J.E., Thelin, G.P., Kolpin, D.W., and Gilliom, R.J., 1999, Distribution of major herbicides in ground water of the United States: U.S. Geological Survey Water-Resources Investigations Report 98-4245, 64 p.

Blajszczak, E.J., Mason, J.P., Watson, K.R., Roberts, S.C., and Miller, K.A., 2005, Water-resources data, Wyoming, water year 2004, Volume 2. Ground Water: U.S. Geological Survey WaterData Report WY-04-2. 


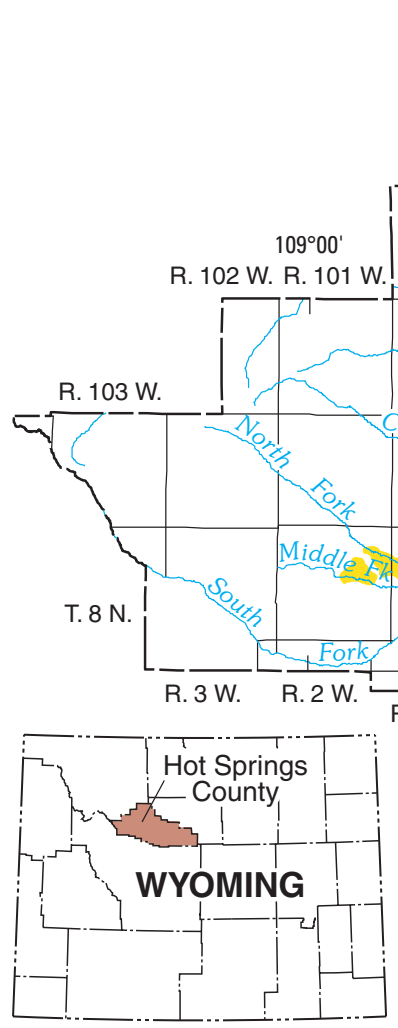

$108^{\circ} 30^{\prime}$
R. 99 W. R. 98 W. R. 97 W
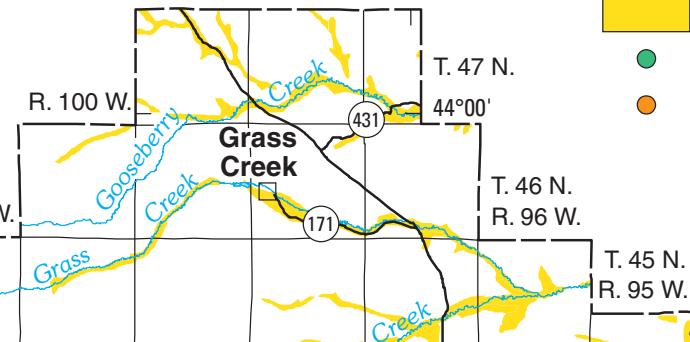
DR. 94 W. R. 93 W.
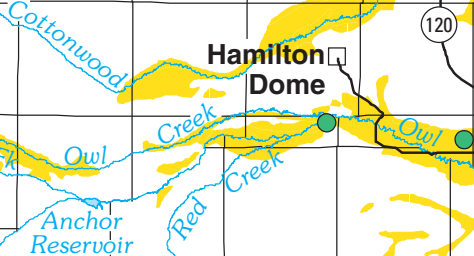
R. $1 \mathrm{~W}$. T. $7 \mathrm{~N}$.

Base modified from U.S. Bureau of the Census digital data, 2001

Public land survey system from Wyoming

Water Resources Center digital data, 1994

Albers Equal-Area Conic projection

Standard parallels $41^{\circ}$ and $45^{\circ}$, central meridian $-108^{\circ} 30$

Figure 3. Location of wells sampled in Hot Springs County, Wyoming, and notation of pesticide detection in each well.

Hamerlinck, J.D., and Arneson, C.S., eds., 1998, Wyoming ground water vulnerability assessment handbook: Volume 2. Assessing ground water vulnerability to pesticides: University of Wyoming, Laramie, Spatial Data and Visualization Center Publication SDVC 98-01-2, variable pagination.

Hutson, S.S., Barber, N.L., Kenny, J.F., Linsey, K.S., Lumia, D.S., and Maupin, M.A., 2004, Estimated use of water in the United States in 2000: U.S. Geological Survey Circular 1268, 46 p.

Meister, R.T., 2002, Farm Chemicals Handbook: Willoughby, Ohio, Meister Publishing Co., variable pagination.
Swanson, R.B., Blajszczak, E.J., Roberts, S.C., Watson, K.R., and Mason, J.P., 2004, Water-resources data, Wyoming, water year 2003, Volume 2. Ground Water: U.S. Geological Survey WaterData Report WY-03-2, 141 p.

U.S. Environmental Protection Agency, 2002, Drinking water regulations and health advisories: EPA 822-R-02-038.

Wyoming Ground-water and Pesticides Strategy Committee, 1999, Wyoming generic state management plan for pesticides and ground water: prepared for Wyoming Department of Agriculture, Cheyenne, Wyoming, 103 p.

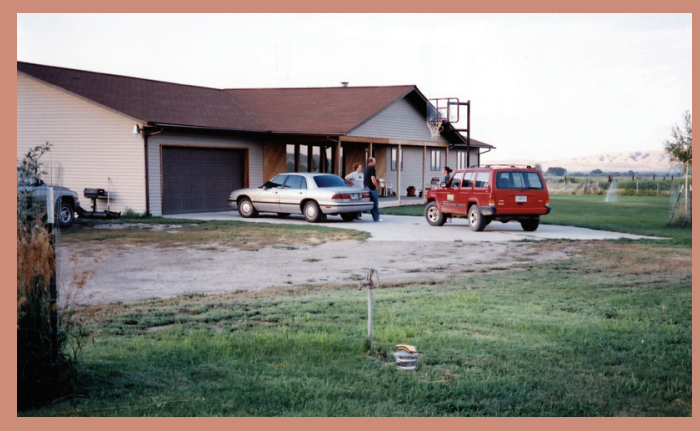

Sampling site south of OwI Creek, west of Thermopolis (photograph by Kendra J. Remley)
EXPLANATION

QUATERNARY ALLUVIAL AND TERRACE DEPOSITS

O PESTICIDE DETECTED IN WELL

ESTICIDE DETECTED IN WELL 